\title{
USE OF ISOZYME ELECTROPHORESIS TO DIFFERENTIATE AMONG ISOLATES OF Macrophomina phaseolina
}

Aly, A. A. ${ }^{1}$; M.A. Abdel-Sattar ${ }^{2}$ and M.R. Omar ${ }^{1}$

1 Plant Pathology Research Institute, Agric. Res. Center, Giza, Egypt.

2 Dept. of Agric. Bot., Faculty of Agric., Suez Canal Univ., Ismailia, Egypt.

\begin{abstract}
The banding patterns of malate dehydrogenase (EC1.1.1.37), glycerol dehydrogenase (EC1.1.1.72), peroxidase (EC1.11.1.7), esterase (EC3.1.1.1), and acid phosphatase (EC3.1.3.2) were determined by polyacrylamide gel electrophoresis for 28 isolates of Macrophomina phaseolina. A total of 96 phenotypes was detected for all the enzymes. Esterase gave the greatest number of polymorphic banding patterns. Cluster analysis of the isozyme banding patterns by the unweighted pairgroup method based on arithmetic means placed the isolates in several groups; however, geographic origin of the isolates or source (host) did not exhibit clear correlation with the isozyme electrophoretic grouping results.
\end{abstract}

\section{INTRODUCTION}

Macrophomina phaseolina (Tassi) Goid., is a deuteromycete soil-borne fungus found throughout the world. It is also one of the most destructive plant pathogens causing charcoal rot, dry-root rot, wilt, leaf blight, stem blight, and damping-off diseases in a wide range of host plants (Dhingra and Sinclare, 1978). M. phaseolina is a monotypic species with a wide host range involving more than 500 species in 75 families (Sinclair, 1982 and Wyllie, 1988).

Differentiation among the pathogenic isolates of $M$. phaseolina is important for improving our understanding of the ecology of these isolates and the epidemiology of the diseases caused by this pathogen. The conventional method of differentiation among pathogen isolates is the observation of the differences in virulence when the isolates interact with a set of host genotypes (Aly, 1988; Ahmed et al., 1991; Schilder and Bergstrom, 1990, and Porta-Puglia et al., 1996). However, this method is expensive, time consuming, and may be influenced by variability inherent in the experimental system (Aly, 1988 and Bhatti and Kraft, 1992). Furthermore, the differential disease reactions do not provide information about the genetic relationship among the pathogen isolates (Perez-Artes et al., 1995). Therefore, another reliable method, either alternative or complementary to that based on the differential interaction between $M$. phaseolina isolates and host genotypes, is required for identification of the pathogenic isolates of $M$. phaseolina. Electrophoresis of isozymes seems to be a suitable method to achieve this goal because the amino acids sequences of polypeptides (components of isozymes) are dependent on nucleotide sequences of their coding genes; therefore an analysis of isozymic variation among isolates of M. phaseolina, approximates an analysis of their genetic variation (Markert and Faulhaber, 1965). 
Aly, A.A. et al.

Isozymes (Isoenzymes) are defined as genetically determined multiple molecular forms of an enzyme. There are three main causes of formation of multiple molecular forms of enzymes. These are 1) the presence of more than one gene locus coding for the enzyme, 2) the presence of more than one allele at a single gene locus coding for the enzyme, and 3) the posttranslation modifications of the formed enzymatic polypeptides resulting in formation of nongenetic or so-called "secondary" isozymes. The term isozymes is usually used to denote multiple molecular forms deriving from different genetic loci, where the term "allozymes" is used to denote multiple molecular forms deriving from different alleles of the same genetic locus. The term "allelic isozymes" is also used by some isozymologists (Manchenko, 1994). Isozymes have similar, if not identical enzymatic properties but slightly different amino acid sequences. Only those isozymes with amino acid compositions of different net charge, or those that result in large differences in the shape of an enzyme, can be differentiated by electrophoresis (Bonde et al., 1993).

Electrophoresis of isozymes has been widely used for studying variation in fungal populations. For example, Sweetingham et al. (1986) examined the pectic isozymes of 140 isolates of Rhizoctonia-like fungi by electrophoresis. The isolates were placed in 11 distinct zymogram groups (ZGs). Isolates within a ZG had a similar cultural and morphological appearance and were all either multinucleate or binucleate. Neate et al. (1988) proposed pectic zymogram patterns as a fast and reliable method of determining AG of $R$. solani. Liu et al. (1990) studied the genetic relationship among 14 isolates of $R$. solani (AG-2) by evaluating electrophoretic data derived from 11 enzyme systems. Three closely related groups, designated A, B and C, were differentiated by isozyme analysis. Laroche et al. (1992) applied isozyme electrophoresis to study the genetic relationship between AGs 3 and 9 of $R$. solani. The banding patterns of seven enzymes were determined by protein PAGE. A total of 76 phenotypes were detected for all the enzymes. Diaphorase gave the most polymorphic banding patterns, followed by esterase and malate dehydrigenase. On the basis of principal components analysis and cluster analysis, the isolates were subsequently divided into two dissimilar and genetically distant groups (I and II). These groups were in agreement with previous AGs 3 and 9. Group I represented all isolates belonging to $\mathrm{Ag}-9$. Group II represented all isolates belonging to AG3 . The isozymes results indicate that the anastomosis grouping concept is genetically based. Damaj et al. (1993) characterized 50 isolates of binucleate Rhizoctonia representing 12 Japanese and five North American anastomosis groups (AGs) by isozyme electrophoretic patterns. Of the 23 enzyme systems screened, eight enzymes with a total of 63 phenotypes were applied to study the genetic relationship among the AGs. Hexokinase and malate dehydrogenase displayed the most polymorphic banding patterns. Cluster analysis of isozyme bands generated four distinct groups (I, II, III, and IV). Isozyme groups of binucleate Rhizoctonia were consistent with prior groupings determined by hyphal anastomosis and by DNA restriction pattern analysis. This study provides evidence that isozyme phenotypes are good indicators of genetic diversity among anastomosis groups of binucleate 
Rhizoctonia species. MacNish et al. (1993) used pectic isozyme (Zymogram) to demonstrate the existence of five distinct groups within $R$. solani AG-8.

In the present study, polyacrylamide gel electrophoresis (PAGE) of five enzyme systems (malate dehydrogenase, glycerol dehydrogenase, peroxidase, esterase, and acid phosphatase) was employed as biochemical tool to differentiate among 28 isolates of $M$. phaseolina.

\section{MATERIALS AND METHODS}

\section{Fungal isolates}

Isolates of $M$. phaeolina (Table 1) used in the present study were obtained from the fungal collection of Cotton Disease Research Section, Plant Pathology Research Institute, Agricultural Research Center, Giza, Egypt. These isolates were originally recovered from cotton and other hosts.

Table 1. Geographic origins and sources of $M$. phaseolina isolates used in electrophoresis.

\begin{tabular}{cll}
\hline Isolate no. & Geographic origin & Source \\
\hline 1 & Giza & Soybean \\
2 & Giza & Sunflower \\
3 & Beheira & Cotton \\
4 & Kafr E-Skeikh & Cotton \\
5 & Faiyoum & Sesame \\
6 & Giza & Sesame \\
7 & Beheira & Cotton \\
8 & Giza & Cotton \\
9 & Daqahliya & Cotton \\
10 & Daqahliya & Cotton \\
11 & Kafr El-Sheikh & Cotton \\
12 & Giza & Soybean \\
13 & Gharbiya & Cotton \\
14 & Sharqiya & Cotton \\
15 & Assiute & Cotton \\
16 & Minya & Cotton \\
17 & Assiute & Cotton \\
18 & Giza & Cotton \\
19 & Giza & Sunflower \\
20 & Gharbiya & Cotton \\
21 & Sohag & Cotton \\
22 & Nobariya & Sesame \\
23 & Giza & Sunflower \\
24 & Minufiya & Cotton \\
25 & Sohag & Cotton \\
26 & Minufiya & Cotton \\
27 & Sharqiya & Cotton \\
28 & Minya & Purslane \\
\hline & &
\end{tabular}


Aly, A.A. et al.

\section{Extraction of fungal proteins}

Protein extracts from $M$. phaseolina isolates were prepared according to Hussein (1992) in the following way: Fungal isolates were grown for 22 days at $22-30^{\circ} \mathrm{C}$ on liquid Czapek medium. The mycelium was harvested by filtration through cheesecloth, washed with distilled water several times, and freeze-dried. This frozen mycelium was suspended in phosphate buffer $\mathrm{pH}$ $8.3(1-3 \mathrm{ml} / \mathrm{g}$ mycelium), mixed thoroughly with glass beads, and ground in liquid nitrogen to a fine powder. The ground mycelium was centrifuged at $19,000 \mathrm{rpm}$ for 30 minutes at $0^{\circ} \mathrm{C}$. The protein content in the supernatant was estimated according to Bradford (1976) by using bovine serum albumin as a standard protein. If protein concentration was low, protein was precipitated from the clarified supernatant by adding ammonium sulphate at $70 \%$ of saturation $(60 \mathrm{~g} / 100 \mathrm{ml})$ then kept in the refrigerator for $30 \mathrm{hr}$. Pellets, collected by centrifugation at $11,000 \mathrm{rpm}$ for 30 minutes, were resuspended in phosphate buffer $\mathrm{pH} 8.3$ and subjected to dialysis for $24 \mathrm{hr}$ against the buffer and centrifugation at $11,000 \mathrm{rpm}$ for 30 minutes. Protein was estimated in the obtained supernatant.

\section{PAGE of native proteins}

Thawed protein-extract supernatant was mixed with an equal volume of a solution containing $20 \%$ glycerol ( $\mathrm{vol} / \mathrm{vol}$ ) and $0.1 \%$ bromophenol blue $(\mathrm{vol} / \mathrm{vol})$ in $0.15 \mathrm{M}$ tris- $\mathrm{HCl}, \mathrm{pH}$ 6.8. Twenty microliters of the resulting suspension (40 to $60 \mu \mathrm{g}$ of protein) was subjected to electrophoresis in 25 $\mathrm{mM}$ Tris buffer containing $192 \mathrm{mM}$ glycine at $\mathrm{pH}$ 8.3. Electrophoresis was conducted at room temperature (approximately 20 to $25^{\circ} \mathrm{C}$ ) for $9 \mathrm{hr}$ on a $15 \%$ polyacrylamide gel with a $6 \%$ stacking gel, at 20 and $10 \mathrm{~mA}$, respectively, until the dye reached the bottom of the separating gel (Laemmli, 1970 and Latrre et al., 1995). Electrophoresis was performed in a vertical slab mold $(16.5 \times 14.5 \times 0.1 \mathrm{~cm})$. Gels were stained according to Manchenko (1994) for the detection of malate dehydrogenase (EC1.1.1.37), glycerol dehydrogenase (EC1.1.1.72), peroxidase (EC1.11.1.7), esterase (EC3.1.1.1), and acid phosphatase (EC3.1.3.2.) isozymes.

\section{Gel analysis}

A gel documentation system (Advanced American Biotechnology 1166 E. Valencia Dr. Unit 6C, Fullerton CA 92631) was used to document the results of PAGE and to cluster the electrophoretic patterns by the unweighted pair-group method based on arithmetic mean (UPGMA).

\section{RESULTS AND DISCUSSION}

Isozyme analysis includes the results obtained from five enzyme systems resolved on polyacrylamide gels. Bands of each enzyme system (Figs. 1, 3, 5,7 , and 9) constituted a number of enzyme banding patterns (zymograms), which varied from one enzyme system to another. Thus, 19, 17, 20, 27, and 13 zymograms were found for malate dehydrogenase, glycerol dehydrogenase, peroxidase, esterase, and acid phosphatase, respectively (Figs. 2, 4, 6, 8, and 10). The geographic origin of the isolates or source (host) did not exhibit clear correlation with the isozyme electrophoretic grouping results. 

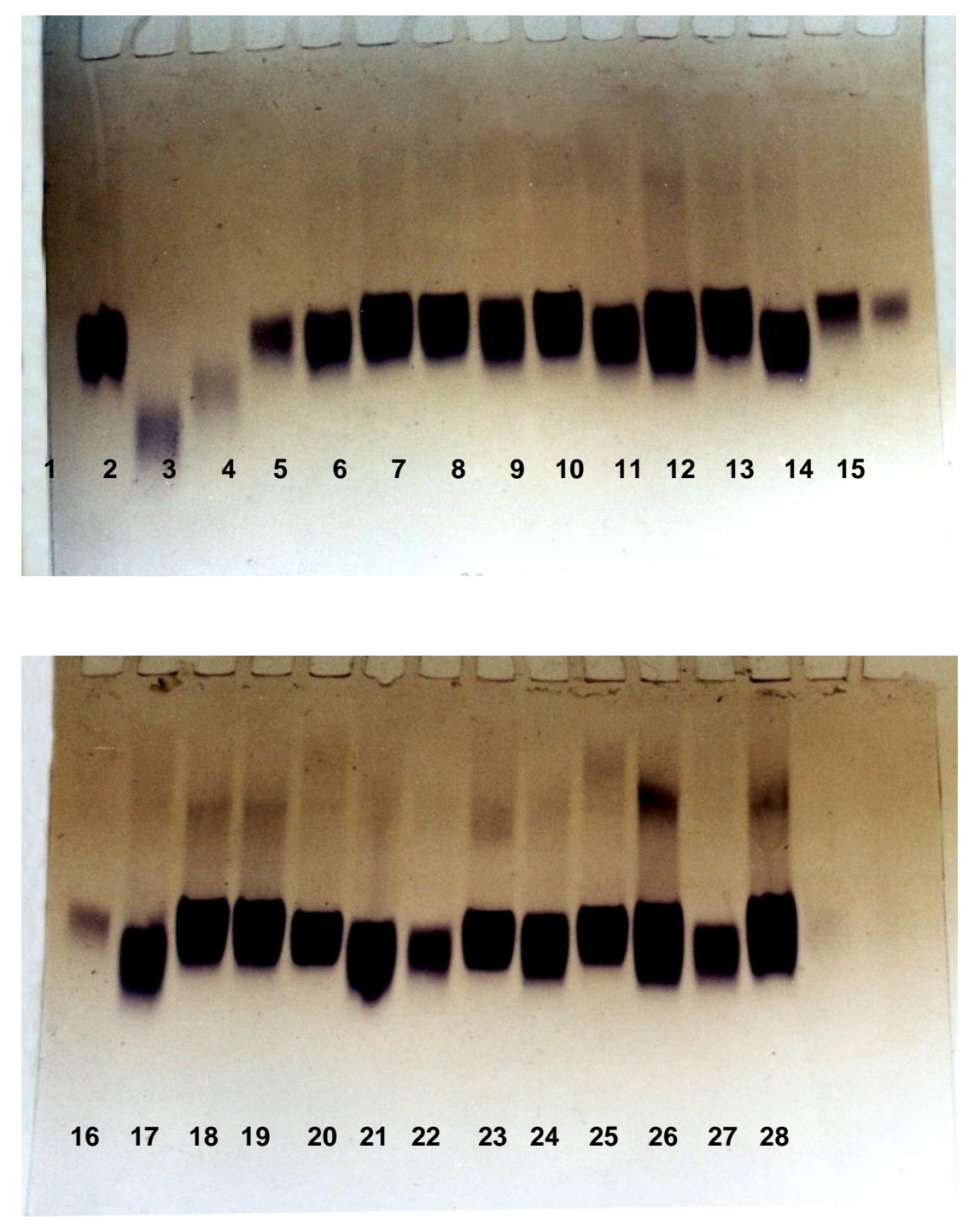

Fig. 1. Malate dehydrogenase isozyme patterns obtained by PAGE from 28 isolates of M. phaseolina. 
Aly, A.A. et al.

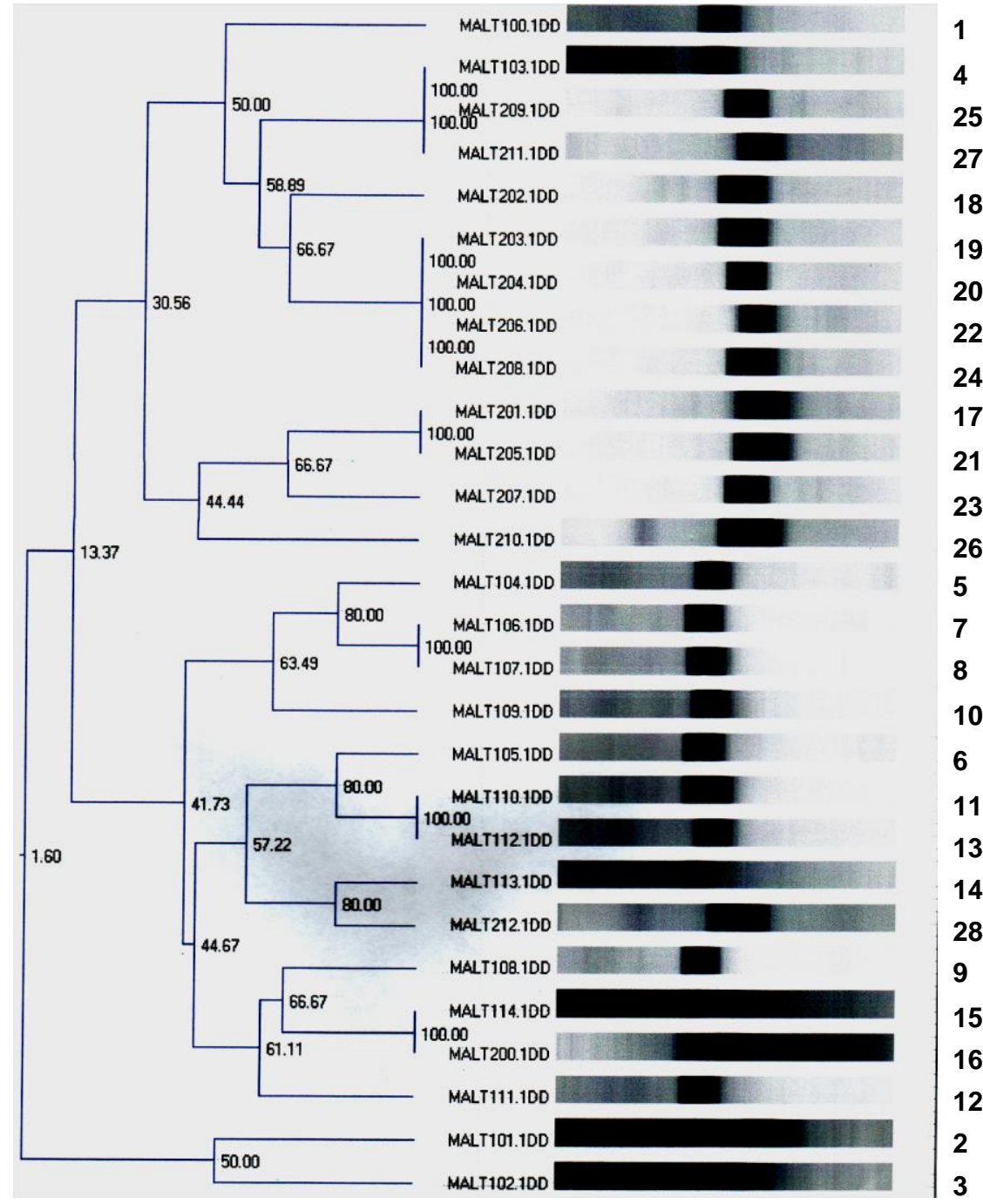

Fig. 2. Phenogram based on average linkage cluster analysis of electrophoretic malate dehydrogenase isozyme patterns obtained by PAGE from 28 isolates of $M$. phaseolina. 

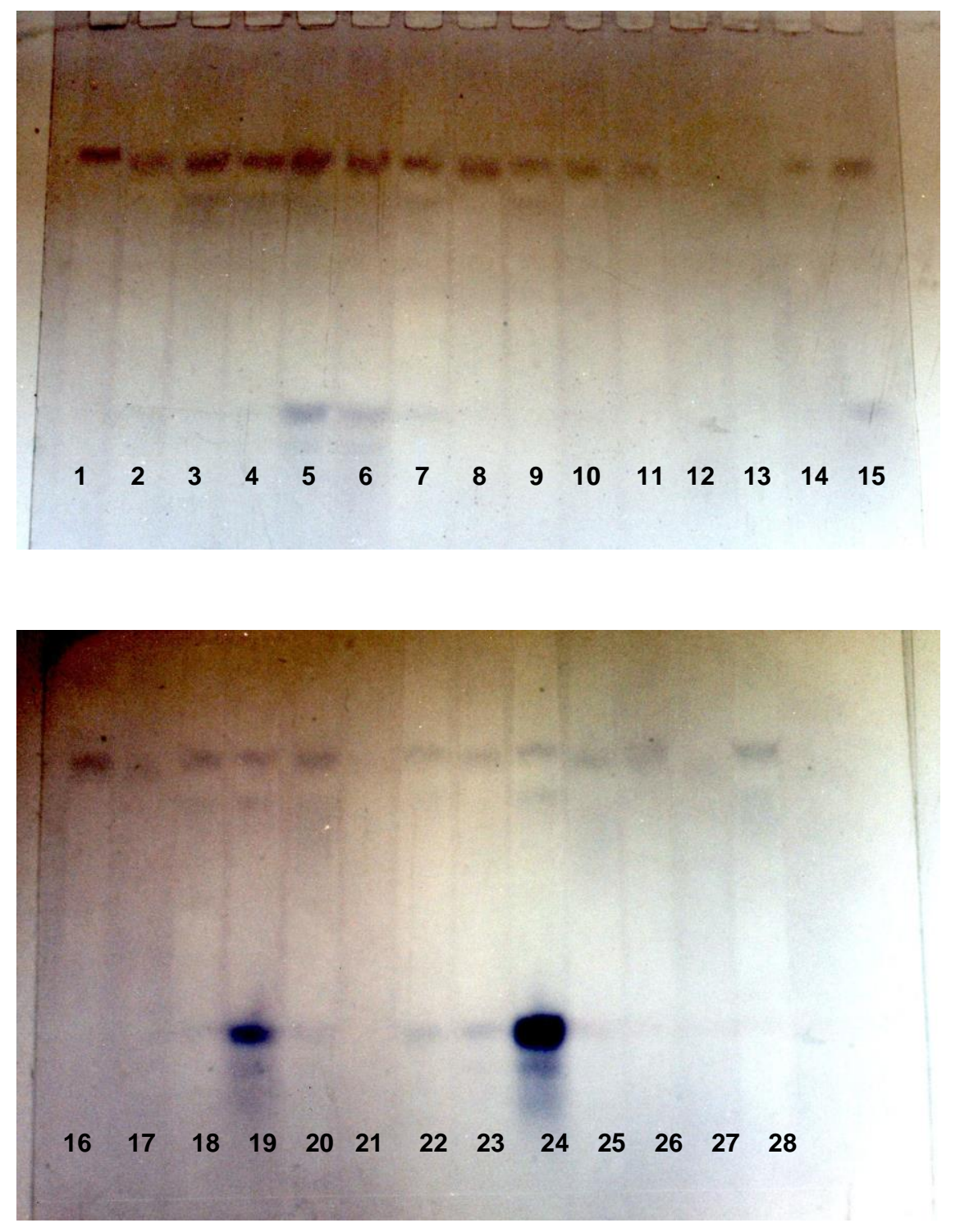

Fig. 3. Glycerol dehydrogenase isozyme patterns obtained by PAGE from 28 isolates of $M$. phaseolina. 


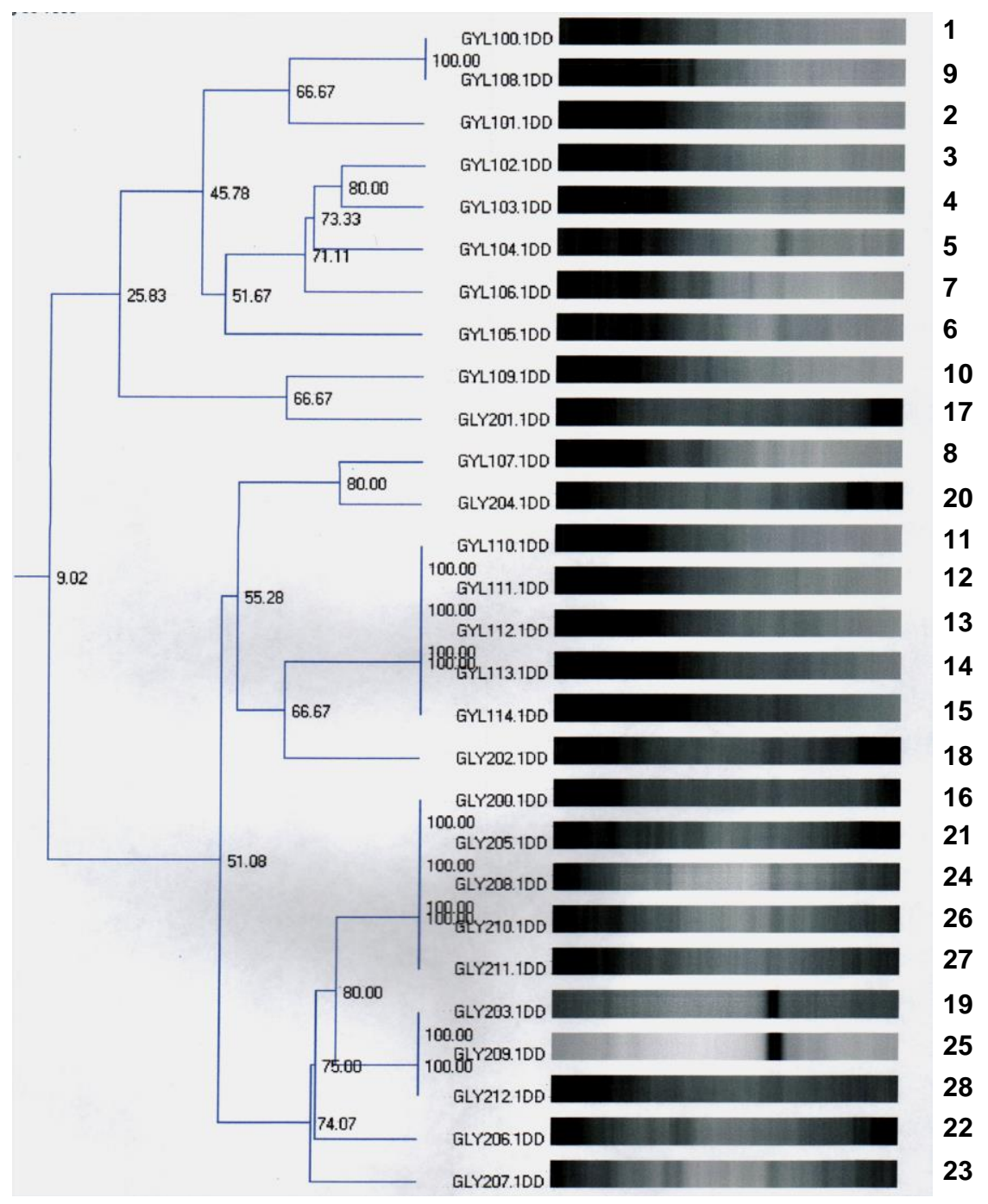

Fig. 4. Phenogram based on average linkage cluster analysis of electrophoretic glycerol dehydrogenase isozyme patterns obtained by PAGE from 28 isolates of $M$. phaseolina. 

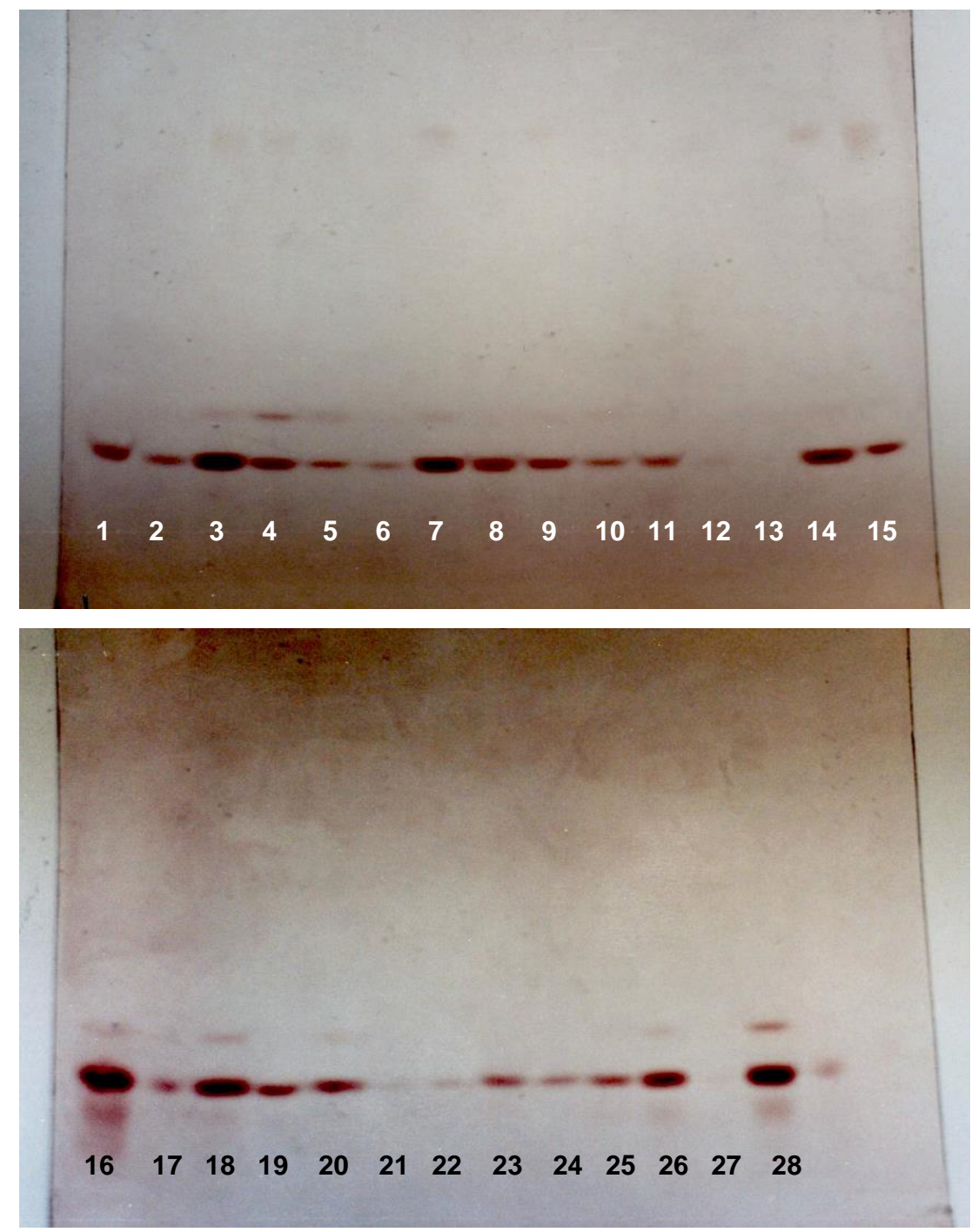

Fig. 5. Peroxidase isozyme patterns obtained by PAGE from 28 isolates of M. phaseolina. 


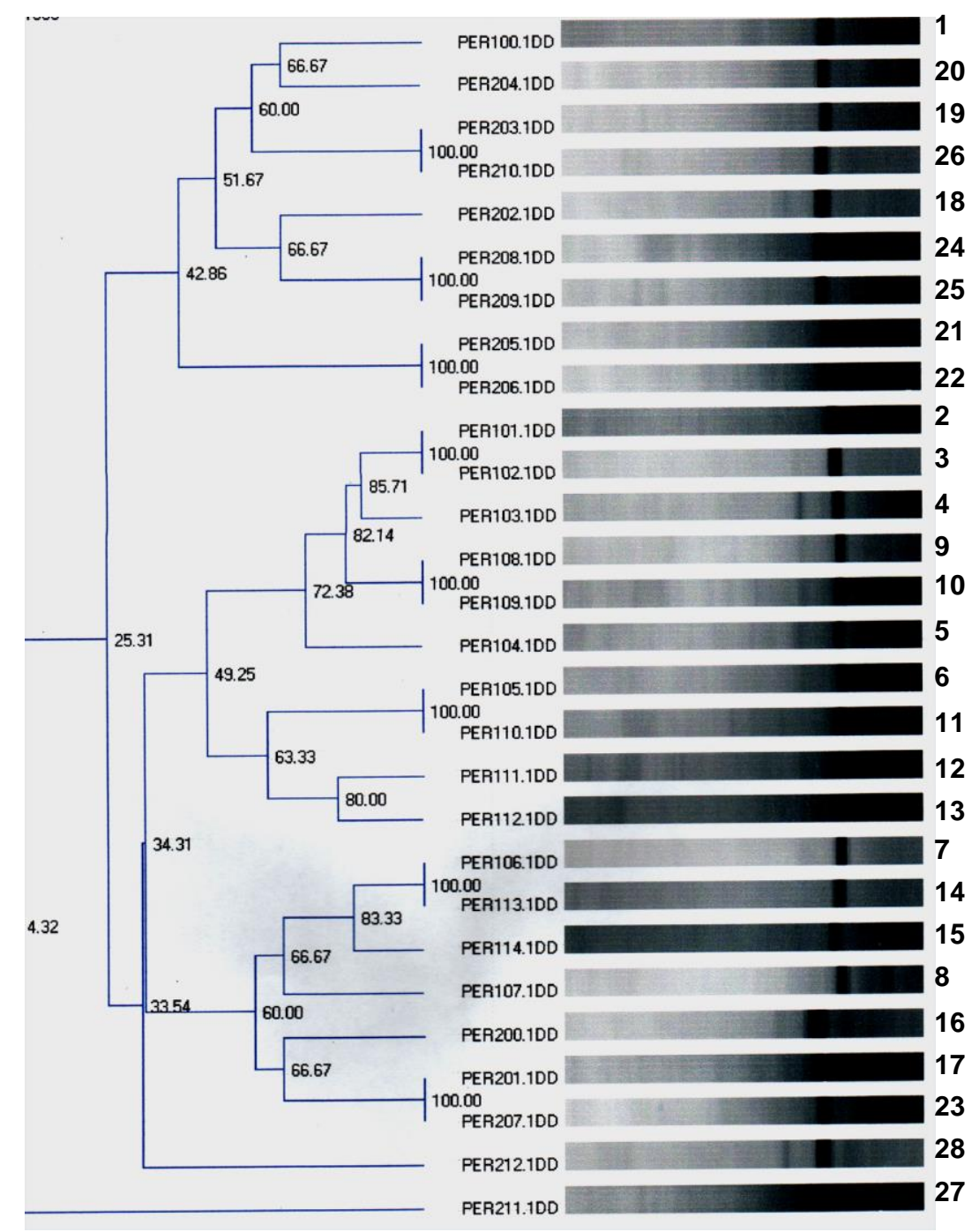

Fig. 6. Phenogram based on average linkage cluster analysis of electrophoretic peroxidase isozyme patterns obtained by PAGE from 28 isolates of $M$. phaseolina. 
J. Agric. Sci. Mansoura Univ., 33 (3), March, 2008
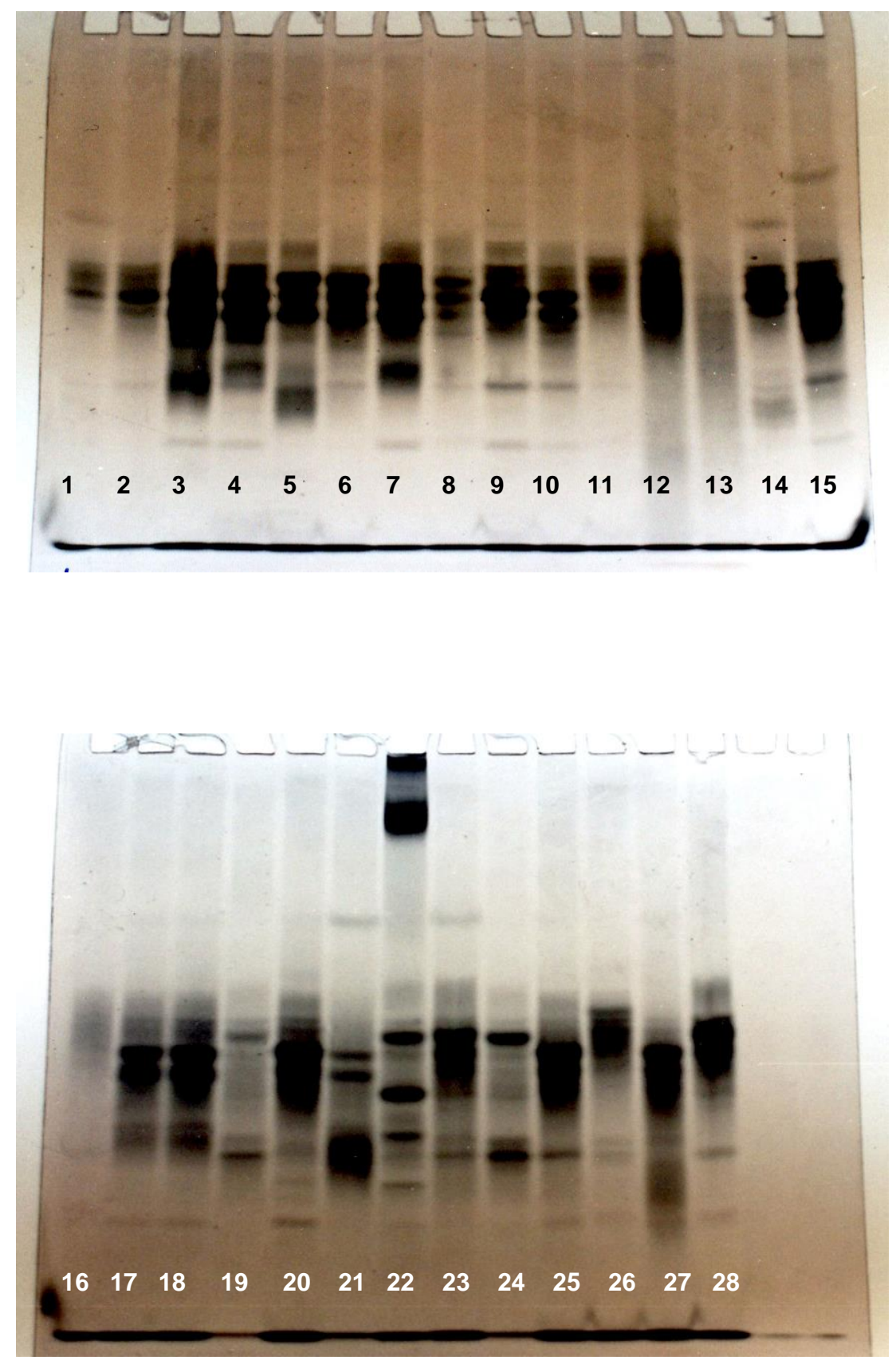

Fig. 7. Esterase isozyme patterns obtained by PAGE from 28 isolates of M. phaseolina. 
Aly, A.A. et al.

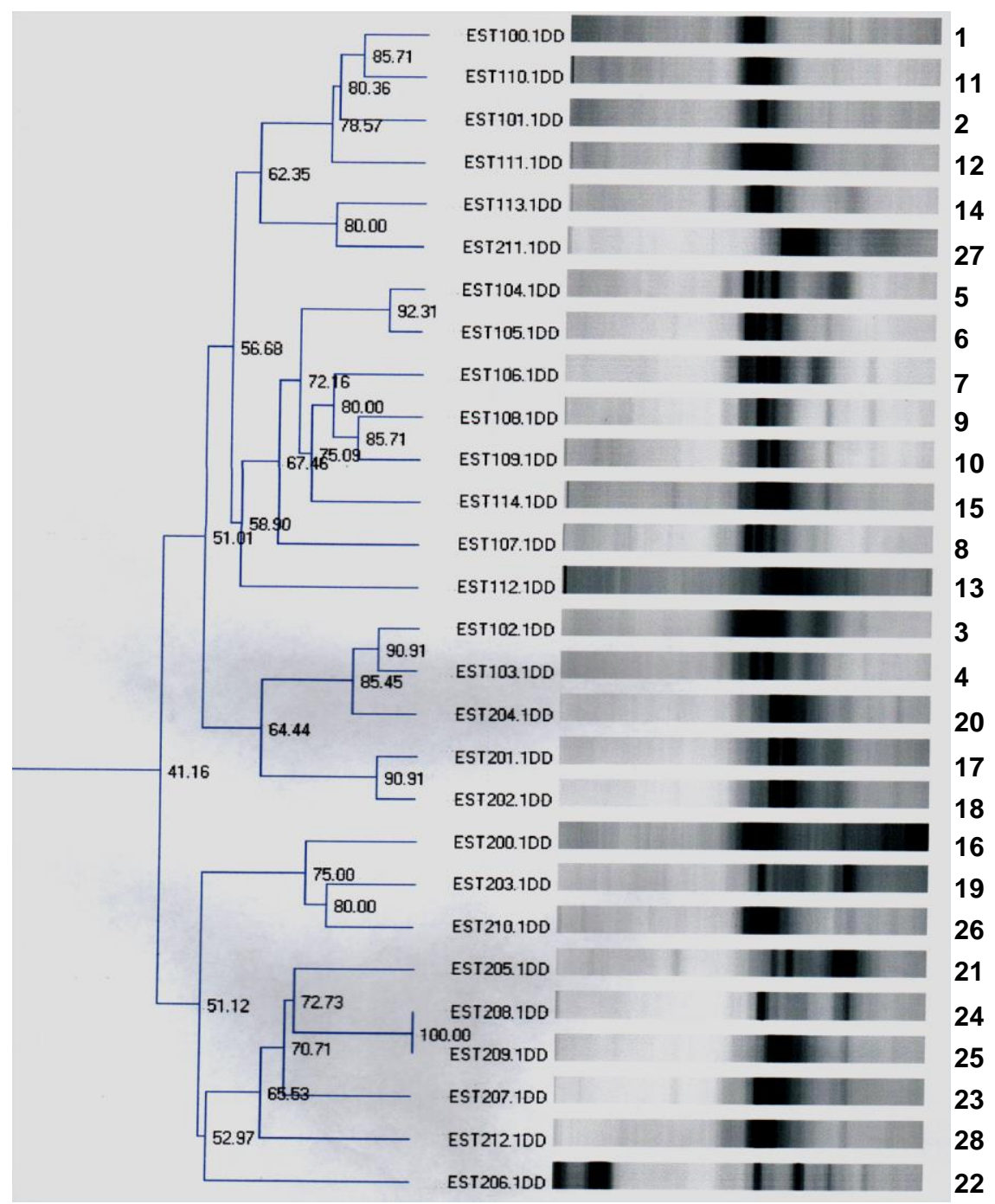

Fig. 8. Phenogram based on average linkage cluster analysis of electrophoretic esterase isozyme patterns obtained by PAGE from 28 isolates of $M$. phaseolina. 

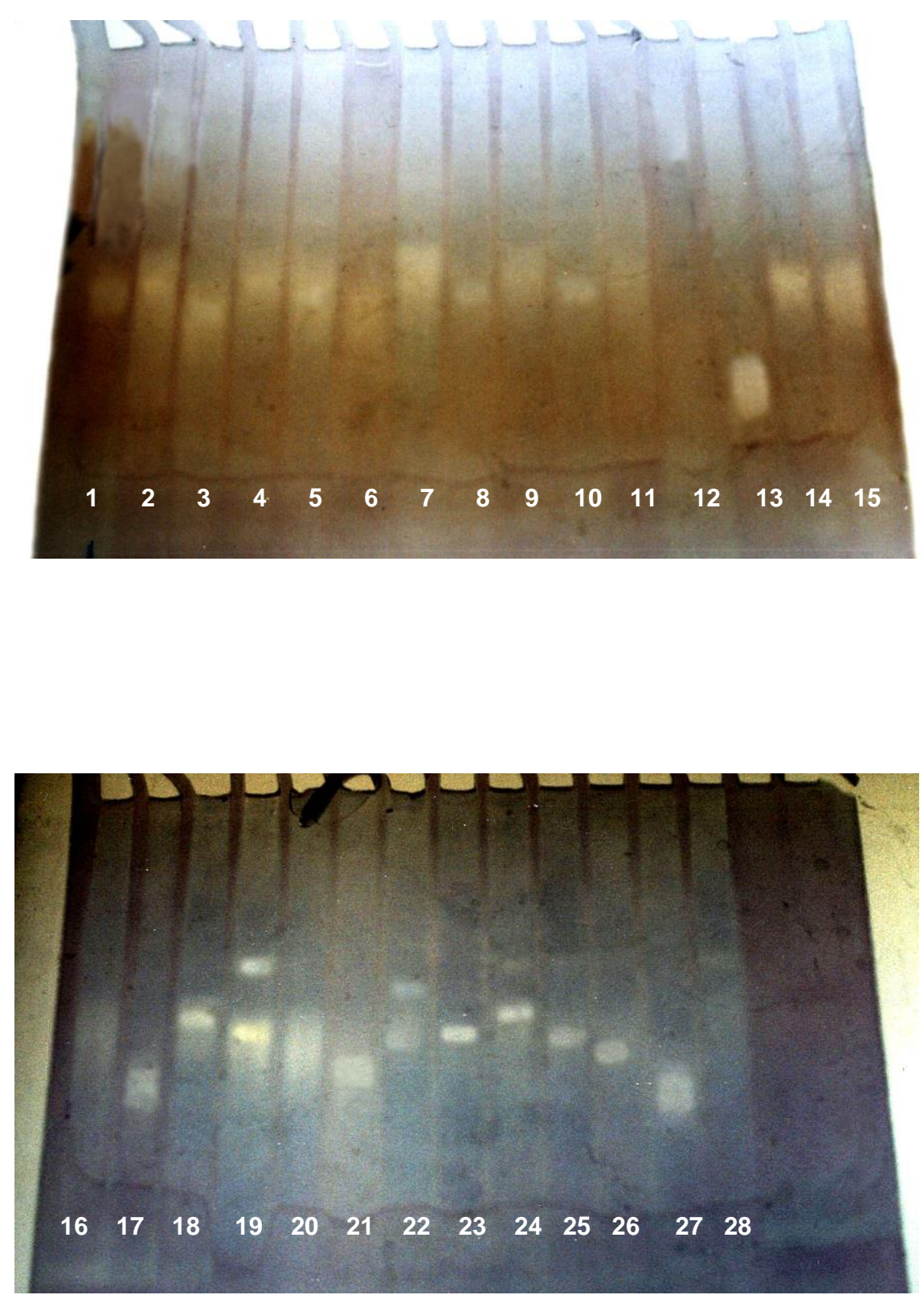

Fig. 9. Acid phosphatase isozyme patterns obtained by PAGE from 28 isolates of M. phaseolina. 
Aly, A.A. et al.

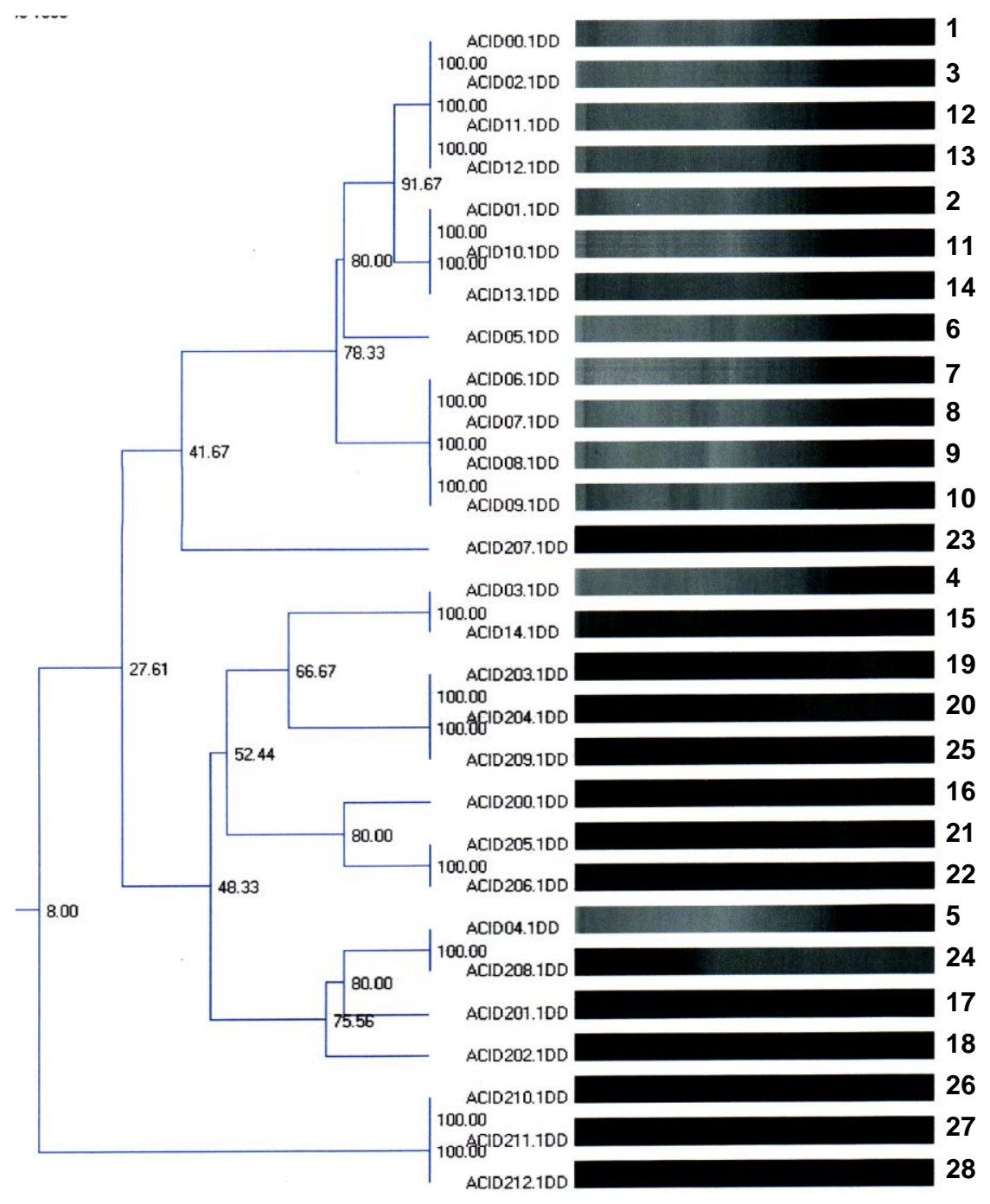

Fig. 10. Phenogram based on average linkage cluster analysis of electrophoretic acid phosphatase isozyme patterns obtained by PAGE from 28 isolates of $M$. phaseolina. 
Isozyme analysis was chosen to identify genetic diversity among $M$. phaseolina isolates because this technique for isolate characterization offers several advantages over techniques for total protein visualization. Isozyme banding patterns are less complex than total protein patterns and are easier to differentiate and interpret. Also, isozyme analyses provide information about protein function, whereas other electrophoretic techniques only separate proteins on the basis of physical properties (Nygaard et al., 1989).

The present study included only 28 isolates of $M$. phaseolina. It is unlikely that this limited number of isolates represents the full range of variation within the fungus. Despite this limitation, a high level of isozymic variation was observed among the isolates. At first, this finding was surprising because a low level of genetic variation is usually observed in populations of fungi that do not reproduce sexually as occurs with $M$. phaseolina; however, in retrospect, it may suggest that parasexualism with fusion of cells from different hyphae may form heterokaryons that contribute to the variation identified. Isozymic variability in the pathogen population may also reflect the lack of resistance among the currently cultivated commercial host cultivars (Almeida et al., 2003).

The high isozymic similarity observed among isolates from different governorates is strong evidence suggesting that such isolates did not evolve independently from each other; therefore, they may be considered as part of the same ancestral population (Almeida et al., 2003). Presumably, the spread of this population from one location to another was by physical means such as seeds, contaminated equipment, or soil infested with microsclerotia.

The isolates of $M$. phaseolina used in the present study were recovered from 5 hosts belonging to 5 different genera. Thus, homogeneity of the isozyme data among isolates from different hosts suggests that selective pressure for host specificity in M. phaseolina in the sampled population has been minimal (Tuskan et al., 1990).

The present study demonstrated that the amount of variation in electrophoretic banding patterns of the tested enzyme systems among $M$. phaseolina isolates is adequate for the application of cluster analysis; therefore, the refinement of isozyme analysis employed in the present work by analyzing more isolates of each host in combination with cluster analysis of the resulting zymograms could provide a reliable method for: (1) rapid grouping of isolates; (2) allocation of unknown isolate to a group and its possible identification; (3) storage of large number of isozymic patterns in data banks for reference; (4) information on epidemiological spreading of isolates (Kersters and DeLey, 1975).

\section{REFERENCES}

Almeida, A.M.R., R.V. Abdelnoor, C.A.A. Arias, V.P. Carvalho, D.S. Jacoud Filho, S.R.R. Marin, L.C. Benato, M.C. Pinto,and C.G.P. Carvalho. 2003. Genotypic diversity among Brazilian isolates of Macrophomina phaseolina revealed by RAPD. Fitopatologia Brasileira 28: 279-285. 
Aly, A.A. et al.

Bhatti, M.A. and J.M. Kraft. 1992. The effects of inoculum density and temperature on root rot and wilt of chickpea. Plant Disease 76:50-54.

Bonde, M.R., J.A. Micales, and G.L. Peterson. 1993. The use of isozyme analysis for identification of plant-pathogenic fungi. Plant Disease 77: 961-968.

Bradford, M.M. 1976. A rapid and sensitive method for the quantification of microgram quantities of protein utilizing the principle of protein-dye binding. Anal. Biochem 72: 248-254.

Damaj, M., S.H. Jabaji-Hare, and P.M. Charest. 1993. Isozyme variation and genetic relatedness in binucleate Rhizoctonia species. Phytopathology 83: 864-871.

Dhingra, O.D., and J.B. Sinclair. 1978. "Biology and pathology of Macrophomina phaseolina". Imprensia Universidade Federal de Viscosa, Brazil $166 \mathrm{p}$.

Hussein, E.M. 1992. Biochemical and serological studies for determining susceptibility of cotton cultivars to Fusarium oxysporum f.sp. vasinfectum (in Russian). Ph.D. Thesis. All-Union Institute of Plant Protection. Leningrad, USSR.

Kersters, J. and J. DeLey. 1975. Identification and grouping of bacteria by numerical analysis of their electrophoretic protein patterns. J. General Microbiol. 87:333-342.

Laemmli, U.K. 1970. Cleavage of structural proteins during the assembly of the head of bacteriophage T4. Nature 227: 680-685.

Laroche, J.P., S.H. Jabaji-Hare, and P.M. Charest. 1992. Differentiation of two anastomosis groups of Rhizoctonia solani by isozyme analysis. Phytopathology 82: 1387-1393.

Latorre, B.A., G.F. Perez, W.F. Wilcox, and R. Torres. 1995. Comparative protein electrophoretic and isozymic patterns of Phytophthora cryptogea isolated from Chilean kiwifruit and North American deciduous fruits. Plant Dis. 79:703-708.

Liu, Z., D.L. Nickrent and J.B. Sinclair. 1990. Genetic relationships among isoaltes of Rhizoctonia solani anastomosis group-2 based on isozyme analysis. Canadian Journal of Plant Pathology 12: 376-382.

MacNish, G.C., D.E. Carling, and K.A. Brainard. 1993. Characterization of Rhizoctonia solani AG-8 from bare patches by pectic isozyme (zymogram) and anastomosis technique. Phytopathology 83: 922-927.

Manchenko, G.P. 1994. "Handbook of Detection of Enzymes on Electrophoretic Gels". CRC Press, Inc., Boca Raton, Florida, 341 p.

Markert, C.L. and I. Faulhaber. 1965. Lactate dehydrogenase isozyme patterns of fish. J. Exp. Zool. 159: 319-332.

Neate, S.M., R.H. Cruickshank, and A.D. Rovira. 1988. Pectic enzyme patterns of Rhizoctonia solani isolated from agricultural soils in South Australia. Trans. Brit. Mycol. Soc. 90: 37-42.

Norwood, J.M., I.R. Crute and K. Phelps. 1984. Variation in seedling susceptibility of Bremia lactucae (lettuce downy mildew) in the absence of effective major resistance genes. Ann. Appl. Biol. 105: 147-157. 
Nygaard, S.L., C.K. Elliott, S.J. Cannon, and D.P. Maxwell. 1989. Isozyme variability among isolates of Phytophthora megasperma. Phytopathology 79: 773-780.

Perez-Artes, E., M.I.G. Roncero, and R.M. Jimenes-Diaz. 1995. Restriction fragment length polymorphism analysis of the mitochondrial DNA of Fusarium oxysporum f.sp. ciceris. J. Phytopathology 143:105-109.

Porta-Puglia, A., P. Crino, and C. Mosconi. 1996. variability in virulence to chickpea of an Italian population of Ascochyta rabiei. Plant Dis. 80: 3941.

Schilder, A.M.C., and G.C. Bergstrom. 1990. Variation in virulence within the population of Pyrenophora tritici-repentis in New York. Phytopathology 80: 84-90.

Sinclair, J.B. ed. 1982. Compendium of soybean diseases. The American Phytopathological Society. St. Paul., Minnesota. $104 \mathrm{p}$.

Sweetingham, M.W., R.H. Cruickshank, and D.H. Wong. 1986. Pectic zymograms and the taxonomy and pathogenicity of the Ceratobasidiaceae. Trans. Brit. Mycol. Soc. 86: 305-311.

Tuskan, G.A., J.A. Walla, and J.E. Lundquist. 1990. Genetic-geographic variation in Peridermium harknessii in the North. Central United States. Phytopathology 80: 857-861.

Wyllie, T.D. 1988. charcoal rot of soybean. pp 106-113. In: Soybean Diseases of the North Central Region (T.D. Wyllie and D.H. Scott, eds.). APS Press, MN, USA.

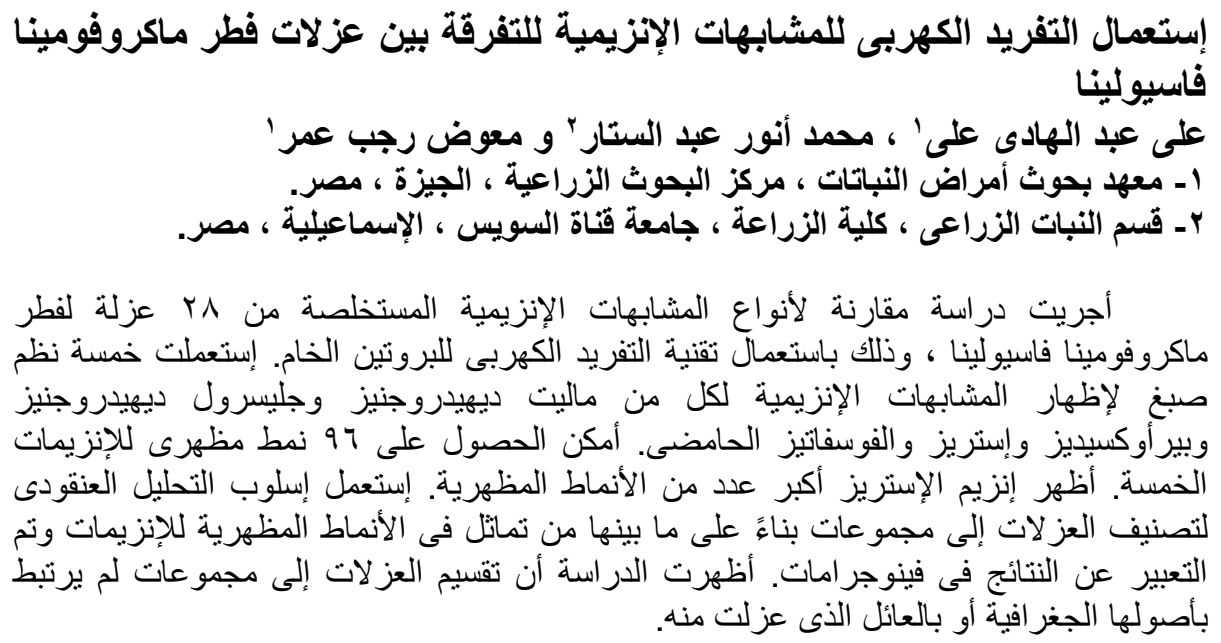

